\title{
Assessment of soil micro flora in rice-wheat cropping system through continuous and rotational herbicide applications
}

\author{
Jagdish Parshad*, Dharam Bir Yadav ${ }^{1}$, Satbir Singh Punia ${ }^{1}$,Kuldeep Singh and Baljeet Singh \\ ${ }^{1}$ Department of Microbiology, C.C.S. Haryana Agricultural University, Hisar (Haryana) India \\ (Email: lect.jagdish@gmail.com)
}

\begin{abstract}
A long term experiment was conducted at CCS Haryana Agricultural University, Regional Research Station, Uchani (Karnal), India. Assessment of fix and rotational herbicides with and without green manure on the microbial population were studied in wheat crop during 2017-18. The treatments included fix/continuous herbicide (Clodinafop) and rotational herbicide (Sulfosulfuron) to control weeds along with weed free and weedy checks. Rhizosphere samples of wheat were collected from different plots of fixed and rotational herbicides treated soil to assess the total bacterial count, phosphate solubilizing microorganisms, actinobacteria, fungi and free-living diazotrophs. Weed free and weedy check served as check (control) for total microbial populations in the soil. Initially, herbicidal application showed negative effect on the soil microbes but retain the number later on as compared to weedy check under both conditions. But the effects of the herbicides on the micro flora in soil could be nullified through green manure.
\end{abstract}

Key Words : Fix herbicides, Rotational herbicides, Green manure, Microbial flora, Rice-wheat

View Point Article : Prashad, Jagdish, Yadav, Dharam Bir, Punia, Satbir Singh, Singh, Kuldeep and Singh, Baljeet (2021). Assessment of soil micro flora in rice-wheat cropping system through continuous and rotational herbicide applications. Internat. J. agric. Sci., 17 (2) : $455-461$, DOI:10.15740/HAS/IJAS/17.2/455-461. Copyright@2021: Hind Agri-Horticultural Society.

Article History : Received : 01.03.2021; Revised : 04.03.2021; Accepted : 17.03.2021

\footnotetext{
* Author for correspondence :

${ }^{1}$ Department of Agronomy, C.C.S. Haryana Agricultural University, Hisar (Haryana) India
} 